\title{
ABSTRAK \\ PENGARUH NANO KURKUMIN TERHADAP FIBROSIS GINJAL AKIBAT OBSTRUKSI URETER UNILATERAL BERDASARKAN MEKANISME SELULER-MOLEKULER
}

\author{
PenelitianEksperimentalpadaTikusPercobaan
}

Obstruksi saluran kemih bagianatasmerupakan salah satu masalah dalam bidang urologi, dapat terjadi pada seluruh fase kehidupan manusia dan lokasinya bisa disepanjang traktus urinariusbagianatas. Akibat dari kondisi ini dapat menyebabkan hidronefrosis yang akan mengakibatkan disfungsi endotel glomeruli dannantinya akan merubah struktur dari ginjal seperti fibrosis interstisial, tubular atrofi dan apoptosis serta inflamasi interstisial. Kurkumin merupakan salah satu senyawa bioaktif dari temulawak(Curcuma xanthorhiza Roxb) dankunyit(Curcuma longa)diharapkan dapat mengatasi fibrosis ini karena sifat anti oksidatif dan anti inflamasinya dengan jalan menekan ekspresi NF-кB, TGF- $\beta 1$ dan MMP-9. Bioavailabilitas kurkumin jelek karena sedikit yang diabsorpsi(5\%), cepat dimetabolisme dan cepat dieliminasi, untuk meningkatkan absorbsinya dibuatlah kurkumin dalam ukuran nano. Tidak seperti kurkumin biasa, nano kurkumin mudah larut dalam air, diserap sampai 96\%. Tujuan penelitian ini untuk membuktikan pengaruh pemberian nano kurkumin terhadap ekspresi NF-кB, TGF- $\beta 1$ danMMP-9 dalam mensupresi fibrosis ginjal akibat obstruksi ureter unilateral.

Penelitianbersifateksperimentaldenganpost test control group designpada 34tikus wistarjantandewasa yang berumur 10-12 minggu yang diikatureternyaunilateral.Terdapat 2 kelompokperlakuan, kelompok yang pertama 17 ekordiberikannanokurkumin 100 $\mathrm{mg} / \mathrm{kgBBselama} 28$ haridari Miso N Korea Selatan, kelompok yang lainnyatidakdiberikan. Setelah 28 haridiperiksaekspresi NF-кB, TGF- $\beta 1$ dan MMP-9secara imunohistokimiadanluas area fibrosis denganMasson Trichromasecarahistokimia.

Hasilpenelitiandidapatkanbahwapadaginjaltikus

yang obstruksitanpapemberiannanokurkuminternyatalebihtinggiekspresinyabiladibandingkandenga npemberiannanokurkumin, yaitu NF- $\mathrm{B}(22,29 \pm 6,18: 13,06 \pm 3,78)$, TGF- $\beta 1 \quad(31,24 \pm 8,82$ : $13,29 \pm 4,93)$ dan MMP-9 $(21,47 \pm 6,45: 12,18 \pm 5,41)$.Hasil ujistatistikketiganyadenganttestmenunjukkanperbedaanyangbermakna $\quad(\mathrm{p}<0,05)$. Sedangkanluas area fibrosis tanpapemberiannanokurkuminternyataditemukanpadaluas fibrosis skor $4(>81 \%)$ sebanyak $64,7 \%$ dandenganpemberiannanokurkumin yang terbanyakditemukanpadaluasfibrosisnyaskor 
3(51\%-80\%) sebanyak52,9\%.Hasil ujistatistikMann-Whitney testmenunjukkanperbedaan yang bermakna $(\mathrm{p}<0,05)$.

KesimpulannyaadalahpemberiannanokurkumindapatmenekanekspresiNF-KB， TGF- $\beta 1$ dan MMP-9juga menekanluas fibrosis yang terjadipadaginjaltikus yang mengalamiobstruksi ureter unilateral.

Kata kunci: nanokurkumin,NF-кB, TGF- $\beta 1$, MMP-9 danfibrosisginjal.

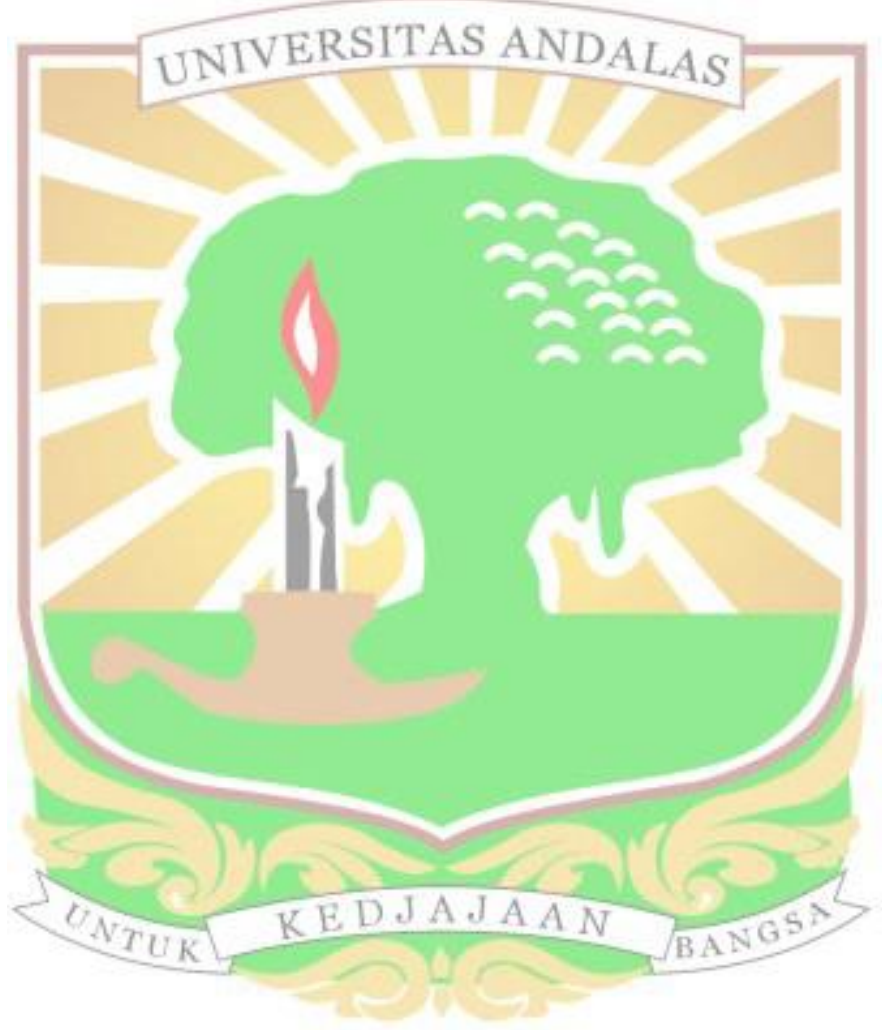




\section{ABSTRACT \\ NANO CURCUMIN EFFECT FOR KIDNEY FIBROTIC CAUSED BY UNILATERAL URETER OBSTRUCTION BASED ON

\author{
CELLULAR-MOLECULAR MECHANISM
}

An experimental study onrat

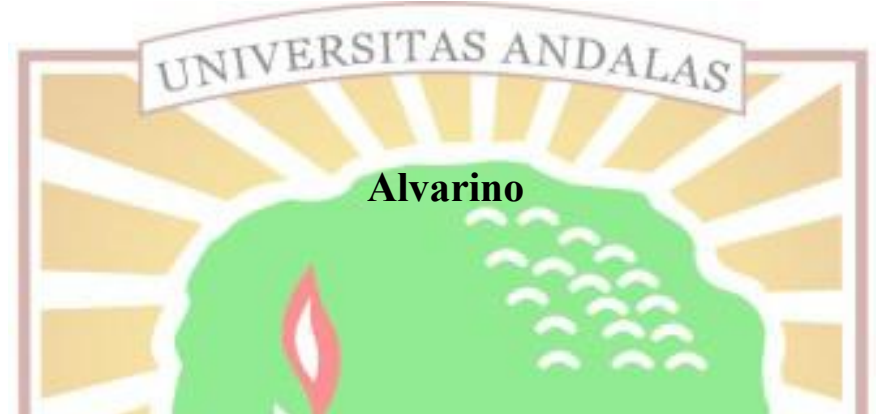

Upper urinary tract obstruction is a such a problem in urology which can occur in any phase of human life and can occur along upper urinary tract. This condition can lead to hydronephrosis. It can make glomerular endothel disfunction and change kidney structure such as interstitial fibrotic, tubular atrophy and apoptosis and also intersticial inflammation. Curcumin is one of bioactive compounds fromtemulawak(Curcuma xanthorhizaRoxb) and turmeric (Curcuma longa) which is expected to resolve fibrotic, this is because the nature of the anti-oxidative and anti-inflammatory supessing the expression NF- $\kappa B$, TGF- $\beta 1$ and MMP-9. The bioavailability of the curcumin is bad because little absorbed (5\%), quickly metabolized and rapidly eliminated. Thus to increase the absorption, curcumin then be made in nano size. Unlike ordinary curcumin, nano curcumin easily soluble in water is absorbed up to $96 \%$. The purpose of this study was to prove the effect of curcumin on the expression of NF- $\kappa$ B, TGF- $\beta 1$ and MMP- 9 supressing fibrosis in the kidney due to obstruction the unilateral ureter.

This research in experimental study with posttest control group designin 34 adult male wistar rats aged 10-12 weeks were tied unilateral ureter. There are two treatment groups, first consisted of 17 rats given curcumin $100 \mathrm{mg} / \mathrm{kg}$ weight for 28 days, while the second group was not given. After 28 days, it examined the expression of NF- $\kappa \mathrm{B}$, TGF- $\beta 1$ and MMP-9 immunohistochemically and area of fibrosis by Masson Trichroma histochemical.

The results of this study was the expression of antibodyin the kidney rats obstruction without administration of nanocurcumin were higher than which given nanocurcumin, that are NF- $\mathrm{B}$ $(22,29 \pm 6,18: 13.06 \pm 3,78)$, TGF- $\beta 1(31,24 \pm 8,82: 13,29 \pm 4,93)$ and MMP-9

$(21.47 \pm 6,45$ $: 12,18 \pm 5,41)$. The statistical tests using t-test shows significant differences $(\mathrm{p}<0.05)$ in that three variable. Thegroup of rats without administration ofnanocurcuminalso has more fibrosis area with score $4(>81 \%)$ about $64,7 \%$, whereas the group of rats which given nanocurcumin has fibrosis area score $3(51 \%-80 \%)$ about $52,9 \%$. The statistical tests using Mann-Whitney shows significant difference $(\mathrm{p}<0.05)$. 
The conclusion isnanocurcumin can suppress the expressionofNF- $\mathrm{B}$, TGF- $\beta 1$ and MMP-9 also the extent of renal fibrosis in rats with unilateral ureteral obstruction.

Keyword :nanocurcumin, NF-кB, TGF- $\beta 1$, MMP-9, kidney fibrosis

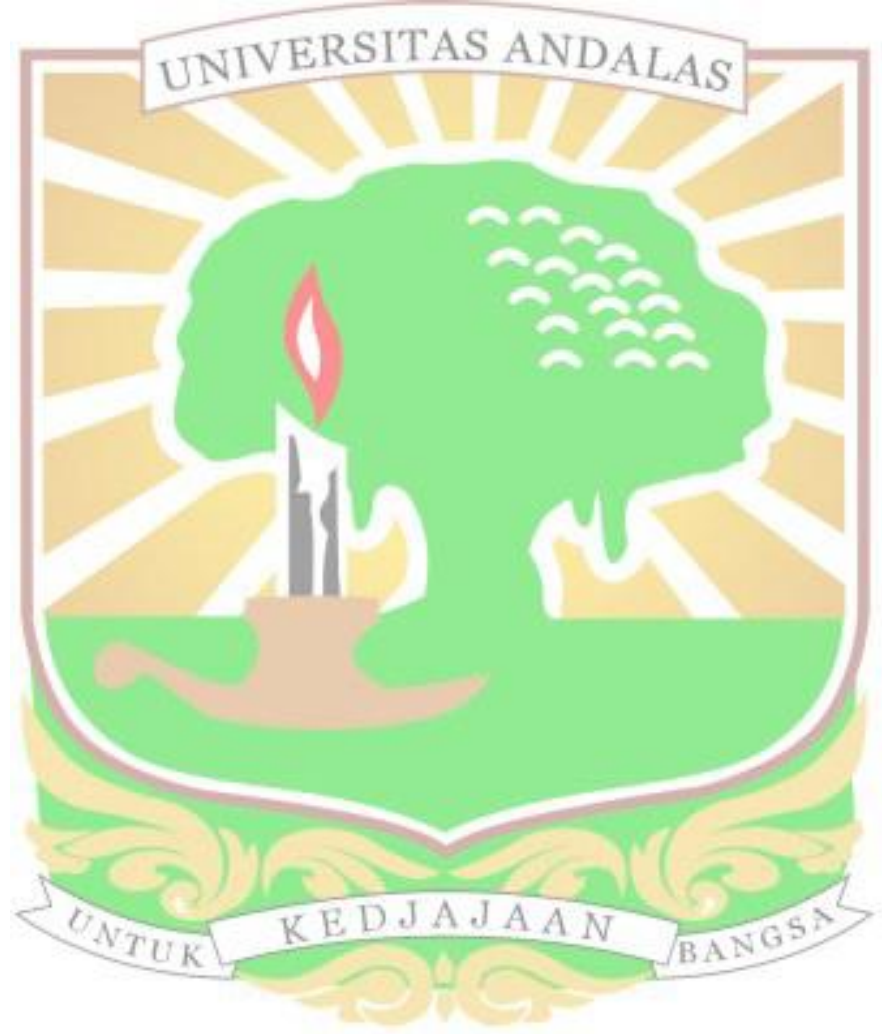

